chưa tầm soát được các nguyên nhân khác.

\section{KẾT LUẦN}

Viêm màng ngoài tim co thắt có đặc điểm lâm sàng nổi bật là triệu chứng của suy tim phải. Siêu âm tim và cắt lớp vi tính đóng một vai trò quan trọng trong việc khẳng định chẩn đoán. Phẫu thuật cắt màng tim rộng rãi đem lại kết quả sớm sau mổ tương đối tốt.

\section{TÀI LIỆU THAM KHẢO}

1. Murat Bicer, Bulent Ozdemir, Iris Kan, et al. Long-term outcomes of pericardiectomy for constrictive pericarditis. Journal of cardiothorac surgery.2015;10:177.

2. B. Cinar, Y. Enc, O. Gokse, et al. Chronic constrictive tuberculous pericarditis: Risk factors and outcome of pericardiectomy. Int J Tuberc Lung Dis.2006;10(6):701-6.

3. Anurag Mehta, Mahaveer Mehta, Abnash $C$. Jan, et al. Constrictive Pericarditis. Clin Cardiol.1999;22(5):334-344.

4. Ana M. Peset, Vicens Marti, Montserrat Cardona, et al. Outcome of Pericardiectomy for Chronic Constrictive Pericarditis. Rev Esp Cardiol. 2007;60(10):1097-101.

5. Yoshiyuki Tokuda, Hiroaki Miyata, Noboru Motomura, et al. Outcome of Pericardiectomy for Constrictive Pericarditis in Japan: A Nationwide Outcome Study. Ann Thorac Surg.2013;96(2):571-6.

6. Adler $Y$, Charron $P$, Imazio $M$, et al. ESC Guidelines for the Diagnosis and Management of Pericardial Diseases. Task Force for the Diagnosis and Management of Pericardial Diseases of the European Society of Cardiology. G Ital Cardiol (Rome).2015;16(12):702-38.

\title{
ĐĂC ĐIỂM MÔ BỆNH HỌC CỦA BÊ̂NH GAN DO RƯợU
}

\section{TÓM TẮT}

Mục tiêu: Xác định đặc điểm mô bệnh học của bệnh gan do rượu. Đối tượng và phương phá: Gồm 60 bệnh nhân mắc bệnh gan do rượu điều trị nội trú tại Bệnh viện Quân y 103, từ tháng 01/2015 đến 7/2017. Các chỉ số nghiên cứu là hình thái gan nhiễm mõ và giai đoan xơ hóa gan theo Metavir, gồm: F0 (không xơ hóa), F1 (xơ hóa nhẹ); F2 (xơ hóa vửa), F3 (xơ hóa nặng) và $F 4$ ( $x o ̛$ gan thực sự). Kết quả và kết luận: $100 \%$ bệnh nhân mắc bệnh gan do rượu có gan nhiễm mỡ. Phần lớn là nhiễm mỡ giot nhỏ $(71,7 \%)$, mức độ nhẹ $(93,3 \%)$ và ở vùng 1 (90,0\%). Một số tổn thương khác hay gặp là thoái hóa hạt $(100 \%)$, thể Mallory $(65,0 \%)$, nhiếm sắc tố $(28,3 \%)$ và biến đổi ưa toan tế bào gan (15,0\%). Đánh giá giai đoạn xơ hóa gan theo phân loại Metavir thấy không xơ hóa gan (F0) là $6,7 \%$; xơ hóa nhe ( $F 1$ ) là $50,0 \%$; xơ hóa gan vừa (F2) là 11,7\%; xơ hóa gan nặng (F3) là $15,0 \%$ và xơ gan thực sự (F4) là 16,7\%.

Tư khóa: Bệnh gan do rượu, mô bệnh học, xơ hóa gan, xơ gan.

\section{SUMMARY \\ HISTOPATHOLOGICAL CHARACTERISTICS OF ALCOHOLIC LIVER DISEASE}

Objective: To determine the histopathological characteristics of alcoholic liver disease. Subjects and methods: 60 patients with alcoholic liver disease were inpatient at 103 Military Hospital, from January 2015 to July 2017. The research indicators are fatty liver morphology and liver fibrosis stage according to

*Học viện Quân y

Chịu trách nhiệm chính: Seng Someth

Email: nguyenvankhoi1980@gmail.com

Ngày nhận bài: 30/6/2021

Ngày phản biên khoa học: 31/7/2021

Ngày duyệt bài: 23/8/2021

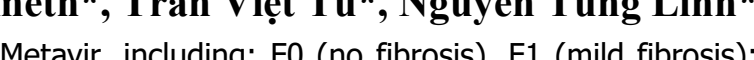
F2 (moderate fibrosis), F3 (severe fibrosis) and F4 (cirrhosis). Results and conclusion: $100 \%$ of patients with alcoholic liver disease had fatty liver. The majority were fatty dropsy (71.7\%), mild (93.3\%), and in zone 1 (90.0\%). Some other common lesions are foamy degeneration $(100 \%)$, Mallory body $(65.0 \%)$, chromophore $(28.3 \%)$ and hepatocellular eosinophilia (15.0\%). Evaluation of liver fibrosis stage according to Metavir classification showed no liver fibrosis (F0) was $6.7 \%$; mild fibrosis (F1) was $50.0 \%$; moderate liver fibrosis (F2) was $11.7 \%$; Severe cirrhosis (F3) was $15.0 \%$ and cirrhosis (F4) was $16.7 \%$.

Keywords: Alcoholic liver disease, histopathology, liver fibrosis, liver cirrhosis.

\section{I. ĐẶT VẤN ĐỀ}

Mô bệnh học là tiêu chuẩn vàng để đánh giá mức độ viêm, hoại tử nhằm tiên lượng, theo dõi điều trị bệnh gan do rượu (BGDR). Khoảng $90 \%$ số người nghiện rượu có gan thoái hóa mõ (GTHM), lúc đầu là vùng 3 , nếu tiếp tục uống rượu tình trạng thoái hóa mõ sẽ nặng, lan tỏa toà̀n gan. Nhiễm mõ gan dưới ba dạng: giọt nhỏ, giọt lớn và hỗn hợp. Trong BGDR, nhiềm mõ gan giọt lớn hay gặp hơn [1], [2], [3].

Thoái hóa hạt do rượu thường gặp ở GTHM do rượu: tế bào gan phồng lên với các hạt trong bào tương phân tán thành các sợi mảnh. Nhân tế bào nhỏ và bắt màu đậm (tăng sắc). Rượu làm tổn thương màng ty thể và làm ty thể phồng to, tạo nên các thể hình cầu trong bào tương. Bên trong những tế bào gan thường thấy các thể Mallory do sự ngưng tập các protein nội bào [4], [5], [6], [7]. Đặc điểm đại thể gợi ý xơ gan do rượu bao gồm khối lượng thùy đuôi lớn hơn, 
nhiều nốt gan sau bên phải, và kích thước ổ tái tạo tế bào gan nhỏ hơn so với xơ gan do virus viêm gan. Sự tăng sinh sợi xơ non và lắng đọng collagen vùng 3 là tổn thương đầu tiên của quá trình xơ gan do rượu. Xơ gan do rượu là xơ gan nốt nhỏ, cấu trúc các vùng không bình thường và tĩnh mạch vùng 3 rất khó tìm thấy. ứ đọng sắt trong tế bào gan (khoảng $1 / 3$ các trường hợp) là do tăng hấp thu sắt ở ruột và lượng sắt trong các đồ uổng có cồn [5], [8].

Nghiên cứu được tiến hành nhằm mục tiêu: Xác định đặc điểm mô bệnh học của bệnh gan do rươu.

\section{II. ĐỐI TƯợNG VÀ PHƯƠNG PHÁP NGHIÊN CỨU}

2.1. Đối tượng nghiên cứu. Gồm 60 bệnh nhân (BN) được chẩn đoán BGDR điều trị nội trú tại Khoa Nội tiêu hóa Bệnh viện Quân y 103, từ tháng 01/2015 đến 7/2017.

\subsection{Phương pháp nghiên cứu}

*Thiết kế nghiên cứu: Nghiên cứu mô tả cắt ngang, có phân tích.

\section{*Các chỉ số nghiên cứu:}

- Sinh thiết gan bằng súng sinh thiết cắt tự động Pajunk của CHLB Đức và kim Deltacut dùng một lần.

- Tiêu chuẩn mẫu mô gan đạt yêu cầu: không chảy máu, không hoại tử, có ít nhất 6 khoảng cửa và chiêu dài mẫu mô gan $>1,5 \mathrm{~cm}$.

- Đánh giá hình thái gan nhiếm mõ chia làm các nhóm sau:

+ Giọt lớn: lipid chiếm toàn tế bào chất của tế bào gan, đầy lệch hạt nhân ra ngoai vi.

+ Giọt nhỏ: lipid phân phối đều trong tế bào chất của tế bào gan, không làm thay đổi vị trí hạt nhân.

+ Hỗn hợp: vừa nhiễm mõ giọt lớn, vừa nhiễm mõ giọt nhỏ.

- Đánh giá mức độ gan thoái hóa mõ chia làm các nhóm sau:

+ Nhẹ: khi số lượng tế bào gan thoái hóa mõ từ $5-33 \%$.

+ Trung bình: khi số lượng tế bào gan thoái hóa mõ từ $34-66 \%$.

+ Nặng: khi số lượng tế bào gan thoái hóa mõ $>66 \%$.

- Đánh giá vùng gan thoái hóa mõ: vùng 1 (quanh tĩnh mạch trung tâm tiểu thùy), vùng 2 (trung gian) và vùng 3 (quanh khoảng cửa).

- Đánh giá giai đoạn xơ hóa gan theo phân loại Metavir: F0 (không xơ hóa gan", F1 (xơ hóa nhẹ: xơ hóa quanh xoang, có hoặc không xơ hóa quanh tế bào); $F 2$ (xơ hóa vừa: xơ hóa khoảng cửa, rất ít các dải xơ), F3 (xơ hóa nặng: xơ hóa khoảng cửa và quanh khoảng cửa, nhiêu dải $x o ̛$ ) và $F 4$ (xơ gan). Trong đó, có xơ hóa gan là $\geq F 1$; xơ hóa gan đáng kể là $\geq F 2 ;$ xơ hóa gan nặng là $\geq F 3$ và $x \sigma$ gan là $=F 4$.

- Các số liệu nghiên cứu được xứ lý theo phương pháp thống kê y sinh học theo chương trình SPSS 22.0.

\section{KẾT QUẢ NGHIÊN CỨU}

Bảng 1. Đặc điểm tổn thương mô bệnh học ở bệnh nhân mắc bệnh gan do rượu.

\begin{tabular}{|c|c|c|c|}
\hline \multicolumn{2}{|c|}{$\begin{array}{l}\text { Đăc điểm gan } \\
\text { thoái hóa mơ }\end{array}$} & \multirow{2}{*}{\begin{tabular}{|c|}
$\begin{array}{c}\text { Số BN } \\
(\mathbf{n}=\mathbf{6 0})\end{array}$ \\
60
\end{tabular}} & \multirow{2}{*}{$\begin{array}{c}\begin{array}{c}\text { Tỷ lệ } \\
(\%)\end{array} \\
100,0\end{array}$} \\
\hline \multicolumn{2}{|c|}{ Thoái hóa mõ tế bào gan } & & \\
\hline \multirow{3}{*}{$\begin{array}{c}\text { Hình thái } \\
\text { gan } \\
\text { thoái hóa } \\
\text { mõ }\end{array}$} & Giọt lớn & 8 & 13,3 \\
\hline & Giọt nhỏ & 43 & 71,7 \\
\hline & Hỗn hợp & 9 & 15,0 \\
\hline \multirow{3}{*}{$\begin{array}{c}\text { Mức độ gan } \\
\text { thoái hóa } \\
\text { mõ }\end{array}$} & Nhẹ $(<33 \%)$ & 56 & 93,3 \\
\hline & Vừa (34- 66\%) & 2 & 3,3 \\
\hline & Nặng (>67\%) & 2 & 3,3 \\
\hline \multirow{3}{*}{$\begin{array}{c}\text { Vùng gan } \\
\text { thoái hóa } \\
\text { mõ }\end{array}$} & Vùng 1 & 54 & 90,0 \\
\hline & Vùng $1+2$ & 4 & 6,7 \\
\hline & Vùng $1+2+3$ & 2 & 3,3 \\
\hline \multirow{4}{*}{$\begin{array}{c}\text { Một số tổn } \\
\text { thương } \\
\text { khác }\end{array}$} & Thoái hóa dạng bọt & 60 & 100,0 \\
\hline & Thể Mallory & 39 & 65,0 \\
\hline & Nhiêm sắc tố & 17 & 28,3 \\
\hline & $\begin{array}{c}\text { Biến đối ưa toan } \\
\text { tế bào gan }\end{array}$ & 9 & 15,0 \\
\hline
\end{tabular}

Qua bảng 1 thấy $100 \%$ BN mắc BGDR có gan nhiễm mõ.

- Hình thái GTHM: giọt nhỏ chiếm tỷ lệ cao nhất $(71,7 \%)$, tiếp đến là GTHM hỗn hợp $(15,0 \%)$ và GTHM giọt lớn (13,3\%).

- Mức độ GTHM: Đa số BN có GTHM mức độ nhe $(93,3 \%)$, GNM mức độ vừa và nặng chiếm tỷ lệ thấp (3,3\% và $3,3 \%)$.

- Vùng GTHM: hầu hết là vùng $1(90,0 \%)$.

- Một số tổn thương khác của BGDR: thoái hóa hạt $(100 \%)$, thể Mallory $(65,0 \%)$, nhiễm sắc tố $(28,3 \%)$ và biến đổi ưa toan tế bào gan $(15,0 \%)$

Bảng 2. Giai đoan xơ hóa gan trên mô bênh hoc

\begin{tabular}{|c|c|c|c|}
\hline $\begin{array}{c}\text { Giai đoạn Xơ hóa } \\
\text { gan trên mô bệnh } \\
\text { học }\end{array}$ & $\begin{array}{c}\text { Số BN } \\
(\mathbf{n = 6 0 )}\end{array}$ & $\begin{array}{c}\text { Tỷ lệ } \\
\mathbf{( \% )}\end{array}$ & $\begin{array}{c}\text { Tần suất } \\
\text { cộng dồn } \\
(\%)\end{array}$ \\
\hline F4 & 10 & 16,7 & 16,7 \\
\hline F3 & 9 & 15,0 & 31,7 \\
\hline F2 & 7 & 11,7 & 43,3 \\
\hline F0 & 30 & 50,0 & 93,3 \\
\hline 4 & 6,7 & 100,0 \\
\hline
\end{tabular}

Đánh giá giai đoạn xơ hóa gan theo phân loại Metavir thây không xơ hóa gan (F0) là 6,7\%; có xơ hóa gan ( $\geq F 1$ ) là $93,3 \%$; xơ hóa gan đáng kể ( $\geq F 2$ ) là $43,3 \%$; $x$ ơ hóa gan nặng $(\geq F 3)$ là 
$31,7 \%$ và xơ gan thực sự (F4) là 16,7\%.

\section{BÀN LUÂिN}

4.1. Đặc điểm gan thoái hóa mõ̃ của bệnh gan do rượu. Đặc điểm mô bệnh học phổ biến nhất của BGDR là tế bào gan thoái hóa mõ, do sự tích tụ các giọt lipid, thường là nhiễm mõ giọt lớn hoặc hỗn hợp. Sự thoái hóa mõ thường bắt đầu từ vùng 3 là vùng được cung cấp máu nuôi dưỡng ít nhất, sau đó lan dần đến vùng quanh khoảng cửa, khi thoái hóa mõ nặng sẽ lan ra toàn bộ tiểu thùy gan [1], [2], [3].

Kết quả nghiên cứu cho thấy $100 \% \mathrm{BN}$ mắc BGDR có tế bào gan thoái hóa mõ. Chủ yếu là GNM giọt nhỏ $(71,7 \%)$, mức độ nhe $(93,3 \%)$ và ở vùng $1(90,0 \%)$, (bảng 1). Nhận xét của chúng tôi cũng tương tự kết quả nghiên cứu của Lê Thị Thu Hiên (2017) ở BN mắc BGDR: 92,8\% các trường hợp có GTHM; chủ yếu là GTHM hỗn hợp (GTHM giọt nhỏ, vừa và lớn): $72,7 \%$; nhiễm mõ mức độ vừa là $39 \%$ và hầu hết GTHM vùng trung tâm (vùng 1): 94,8\% [1]. Lê Quốc Tuấn (2019) cũng thấy nhiễm mõ hỗn hợp chiếm tỷ lệ cao nhất (69,5\%). Mức độ nhiễm mỡ từ 34- 66\% chiếm tỳ lệ $42,1 \%$. Thoái hóa mõ gan vùng 1 chiếm tỳ lệ $95,8 \%$, vùng 2 là $71,6 \%$, vùng 3 là $69,5 \%$ [2].

Nghiên cứu của Vũ Thị Thu Trang (2019) ở bệnh nhân GTHM cho thấy phần lớn các trường hợp $(63,7 \%)$ là thoái hóa mõ hạt to và hỗn hợp cả hạt to và hạt nhỏ nhưng thoái hóa mõ hạt to vẫn là chủ đạo $(33,4 \%)$, chỉ có $2,9 \%$ là thoái hóa mõ hạt nhỏ là chính. Chủ yếu là thoái hóa mõ độ $1(41,2 \%)$ và độ $2(44,1 \%)$, thoái hóa mõ nặng độ 3 chỉ chiếm 14,7\%. Ở giai đoạn GTHM đơn thuần, $100 \%$ thoái hóa mõ mức độ nhẹ, ở giai đoạn viêm gan nhiễm mõ có các mức độ thoái hóa mõ khác nhau trong đó chủ yếu là mức độ trung bình (50\%). Thoái hóa mõ lan tỏa toàn bộ gan chiếm $74,5 \%$, thoái hóa mõ vùng 3 chiếm 22,6\%. Không thấy có sự khác biệt về kiểu thoái hóa mõ, mức độ nhiếm mõ và vị trí thoái hóa mõ giữa hai nhóm GTHM do rượu và GTHM không do rượu [3].

\section{2. Đăc điểm một số tổn thương khác} trên mô bệnh học của bệnh gan do rượu. Thoái hóa hạt do rượu thường gặp trong BGDR, tế bào gan phồng lên với các hạt trong bào tương, các hạt này thường phân tán thành các sợi mảnh. Nhân tế bào nhỏ và bắt màu đậm (tăng sắc). Bọt hình thành do giữ nước và mất khả năng tiết protein của các vi ống từ tế bào gan. Rượu làm tổn thương màng ty thể và làm ty thể phồng to lên. Phồng tế bào gan là tổn thương tế bào gan cơ bản trong bệnh GTHM, đây là một dạng chết tế bào theo chương trình (apoptosis). Phồng tế bào gan có thể được sửa chữa phục hồi nhưng phần lớn sẽ tiến tới ly giải tế bào. Bên trong những tế bào gan thường thấy các thể Mallory do sự ngưng tập các protein nội bào [1], [2], [3].

Qua nghiên cứu thấy ở BN mắc BGDR thấy $100 \%$ số BN có thoái hóa dạng bọt, thể Mallory là $65,0 \%$, nhiễm sắc tố là $28,3 \%$ và biến đổi ưa toan tế bào gan $(15,0 \%)$ (bảng 1$)$. Điều này cũng tương tự nhận xét của Lê Thị Thu Hiền (2017): hay gặp là thoái hóa hạt do rượu $(84,3 \%)$, ty thể khổng lồ $(63,4 \%)$ và thể Mallory $(60,2 \%)[1]$; của Lê Quốc Tuấn (2019): thoái hóa hạt do rượu $(84,2 \%)$, nhiễm sắc tố $(56,8 \%)$, thể Mallory $(64,2 \%)$, ty thể khổng lồ $(62,1 \%)$ và biến đổi ái toan $(63,2 \%)$ [2].

Nghiên cứu của Vũ Thị Thu Trang (2019) cho thây có $92,2 \%$ bệnh nhân GNM có phồng tế bào gan, trong đó có $49 \%$ các trường hợp có phồng tế bào gan mức độ nhiều. Nhóm viêm GTHM và xơ gan $100 \%$ có phồng tế bào gan trong khi nhóm GTHM đơn thuần chỉ có $33,3 \%$ có phồng tế bào gan. Không có sự khác biệt về tỷ lệ phồng tế bào gan giữa nhóm GTHM do rượu và GTHM không do rượu. Có 35,3\% bệnh nhẩn GTHM có thể Mallory, nhưng chỉ có $16,3 \%$ bệnh nhân GNM không do rượu có thể Mallory, ngược lại, có tới $55,9 \%$ bệnh nhân GTHM do rượu có tổn thương này. Có $16,7 \%$ bệnh nhân GTHM có ty thể khổng lî̀, chủ yếu là các bênh nhân GTHM do rượu $(32,4 \%)$ và chỉ có $4,7 \%$ ở nhóm GTHM không do rượu, sự khác biệt có ý nghĩa thống kê $(p<0,05-0,001)$ [3].

4.3. Đắc điểm xơ hóa gan trên mô bệnh học. Xơ hoá gan là do chuyển dạng của tế bào sao thành tế bào xơ non. Mức độ xơ hóa phụ thuộc vào tân suất tái phát, thời gian bị bệnh và mức đô bênh. Sự phát triển từ xơ hóa gan và cuối cùng dẫn đến xớ gan là đặc điểm phổ biến tất cả BN bệnh gan mạn tính. Theo phân loại Metavir: xơ hóa gan nhe là xơ hóa quanh xoang (F1), xơ hóa gan vừa là xơ hóa khoảng cửa (F2), xơ hóa nặng là nhiều dải xơ khoảng cửa và quanh khoảng cửa $(\mathrm{F} 3)$ và xơ gan (F4) [1], [2], [3].

Chúng tôi đánh giá giai đoạn xơ hóa gan theo phân loại Metavir thấy không xơ hóa gan (F0) là $6,7 \%$; xơ hóa gan nhẹ ( $F 1)$ là $50,0 \%$; xơ hóa gan vừa (F2) là $11,7 \%$; xơ hóa gan nặng (F3) là $15,0 \%$ và xơ gan thực sự (F4) là $16,7 \%$. Tỷ lẹ có xơ hóa gan $(\geq F 1)$ là $93,3 \%$, xơ hóa gan đáng kể ( $\geq F 2$ ) là $43,3 \%$ và xơ hóa gan nặng $(\geq F 3$ ) là $31,7 \%$. Tần suất xơ hóa gan ở BN mắc $B G D R$ 
trong nghiên cứu của chúng tôi cũng tương tự kết quả nghiên cứu của Lê Thị Thu Hiền (2017): xơ hóa gan F2 $(24,1 \%)$ và $F 3(25,3 \%)$ chiếm tỷ lệ cao nhất, xơ hóa gan $\mathrm{F} 4$ chiếm tỷ lệ thấp nhất (14,5\%) [1]; của Lê Quốc Tuấn (2019): BN giai đoạn viêm gan do rượu chiếm tỷ lệ là $87,4 \%$. Giai đoạn xơ hóa theo Metavir: giai đoạn F2 và $\mathrm{F} 3$ chiếm tỷ lệ lần lượt là $26,3 \%$ và $25,3 \%$; xơ hóa gan thực sự (F4) là 12,6\%. Mức độ xơ hóa gan đáng kể ( $\geq F 2$ ) chiếm tỷ lệ là $62,1 \%$ [2].

Nghiên cứu của Vũ Thị Thu Trang (2019) ở bệnh nhân GTHM cho thây loại xơ hóa hay gặp là xơ hóa quanh tế bào $(95,1 \%)$, xơ hóa quanh mao mạch nan hoa $(92,1 \%)$, xơ hóa khoảng cửa và quanh khoảng cửa $(80,4 \%)$. Tỷ lệ vách xơ là $22,5 \%$, cầu xơ là $14,7 \%$ và xơ gan là $4,9 \%$. Không có sự khác biệt về tỷ lệ xơ hóa quanh mao mạch nan hoa và quanh tế bào giữa hai nhóm GTHM do rượu và không do rượu. Tuy nhiên, tỷ lệ xơ hóa khoảng cửa và quanh khoảng cửa ở nhóm GTHM do rượu $(94,1 \%)$ cao hơn nhóm GTHM không do rượu $(62,8 \%)$, sự khác biệt có ý nghĩa thống kê với $p<0,001$ [3].

Như vậy, xơ hóa gan do rượu, xuất hiện đầu tiên vùng 3 và là minh chứng rằng $\mathrm{BN}$ uống nhiều rượu. Những $B N$ có xơ hóa gan đáng kể ( $\geq$ F2) cần được điều trị ngay, để tránh tiến triển thành xơ hóa gan nặng. Đối với $B N$ có xơ hóa gan nặng ( $\geq F 3)$, cần theo dõi để phát hiện biến chứng ung thư gan, giãn võ̃ tĩnh mạch thực quản.

\section{KẾT LUẬN}

- 100\% bệnh nhân mắc bênh gan do rượu có gan thoái hóa mỡ. Phần lớn là thoái hóa mở giọt nhỏ $(71,7 \%)$, mức độ nhe $(93,3 \%)$ và ở vùng 1 (90,0\%). Một số tổn thương khác hay gặp là thoái hóa hạt $(100 \%)$, thể Mallory $(65,0 \%)$, nhiễm sắc tố $(28,3 \%)$ và biến đổi ưa toan tế bào gan $(15,0 \%)$.

- Đánh giá giai đoạn xơ hóa gan theo phân loại Metavir thấy không xơ hóa gan (F0) là $6,7 \%$; xơ hóa nhe (F1) là $50,0 \%$; xơ hóa gan vừa (F2) là $11,7 \%$; xơ hóa gan nặng (F3) là $15,0 \%$ và xơ gan thực sự (F4) là $16,7 \%$.

\section{TÀI LIẸU THAM KHẢO}

1. Lê Thi Thu Hiền (2017), Nghiên cứu một số đặc điểm lầm sàng, cận lâm sàng và chỉ số chống oxy hóa trong máu ở bệnh nhân mắc bệnh gan do rượu, Luận án Tiễn sĩ y học, Đại học YD Thái Nguyên.

2. Lề Quốc Tuấn (2019), Nghiên cứu đă̆c điểm lâm sàng, cận lâm sàng và nồng đố một số cytokin huyết tương trên bệnh nhân mắc bểnh gan mạn do rượu, Luận án Tiên sĩ y học, Đại học YD Thái Nguyên.

3. Vũ Thị Thu Trang (2019), Nghiên cứu đăcc điểm lâm sàng, một số xét nghiệm, siêu âm và mồ bệnh hoc bệnh gan nhiếm mỡ, Luận án Tiến sĩ y học, Viện NCKHYDLS 108

4. Altamirano J., Miquel R., Katoonizadeh A. et al. (2014), "A histologic scoring system for prognosis of patients with alcoholic hepatitis", Gastroenterology, 146: 1231-1239.

5. Celli R., Zhang X. (2014), "Pathology of Alcoholic Liver Disease", Journal of Clinical and Translational Hepatology, vol. 2, 103-109.

6. Dubois M., Sciarra A., Trépo E. Et al. (2020), "Histologic parameter score does not predict shortterm survival in severe alcoholic hepatitis", United European Gastroenterol J., 8(9):1003-1012.

7. Ntandja Wandji L. C., Gnemmi V. et al. (2020), "Combined alcoholic and non-alcoholic steatohepatitis", JHEP Rep., 2(3): 100- 101.

8. Sakhuja P. et al (2014), "Pathology of alcoholic liver disease, can it be differentiated from nonalcoholic steatohepatitis? World J Gastroenterol., 20 (44): 16474-16479.

\title{
ĐẶC ĐIỂM MộT Số CHỈ Số HUYẾT HỌC VÀ ĐÔNG MÁU Ở BÊ̂NH GAN DO RƯợU
}

\author{
Seng Someth*, Trần Việt Tú*, Nguyễn Tùng Linh*
}

\section{TÓM TẮT}

Muc tiêu: Xác định đặc điểm và mối liên quan một số chỉ số huyết học và đông máu với mô bệnh hợ ở bênh gan do rượu. Đối tượng và phướng pháp: Gồm 60 bệnh nhân mắc bệnh gan do rượu điều

\footnotetext{
*Hoc viên Quân y

Chịu trách nhiệm chính: Seng Someth Email: nguyenvankhoi1980@gmail.com Ngày nhận bài: $1 / 7 / 2021$

Ngày phản biên khoa học: 1/8/2021

Ngày duyệt bài: 25/8/2021
}

trị nội trú tại Bênh viện Quân y 103, từ tháng 01/2015 đến $7 / 2017$. Các chỉ số nghiên cứu là số lượng hồng cầu, hàm lượng hemoglobin, số lượng bạch câu, số lượng tiểu cầu, tỷ lệ Prothrombin, thời gian APTT, nồng độ Fibrinogen và chỉ số INR. Kết quả và kết luân: $45,0 \%$ số bệnh nhân mắc bênh gan do rươu giảm số lượng hồng câu <4,2 T/l; 16,7\% bệnh nhẩn giảm nồng độ hemoglobin $<120 \mathrm{~g} / \mathrm{l}$ và $35,0 \%$ số bệnh nhân giảm số lượng tiểu cầu $<140 \mathrm{G} / \mathrm{l}$. Nồng độ $\mathrm{Hb}$ và số lượng tiểu cầu tương quan nghịch với giai đoạn xơ hóa gan trên mô bênh hoc $(r=-0,25$ và $r=-0,28$; $\mathrm{p}<0,05)$. Có $6,7 \%$ bệnh nhân giảm tỷ lệ Prothrombin $<70 \%$; có 3,3\% bệnh nhân tăng chỉ số INR >1,3. Có $13,3 \%$ bệnh nhân giảm nồng độ Fibrinogen <2 $\mathrm{g} / \mathrm{l}$ và 